\title{
Reseña de la película Desobediencia o cómo entrenar gallos de pelea de Juan Pablo Ortiz "Tuchi" (2018)*
}

Sergio Elías Ortiz Tohón

Universidad Nacional de Colombia, Bogotá, Colombia sergioortizred@gmail.com

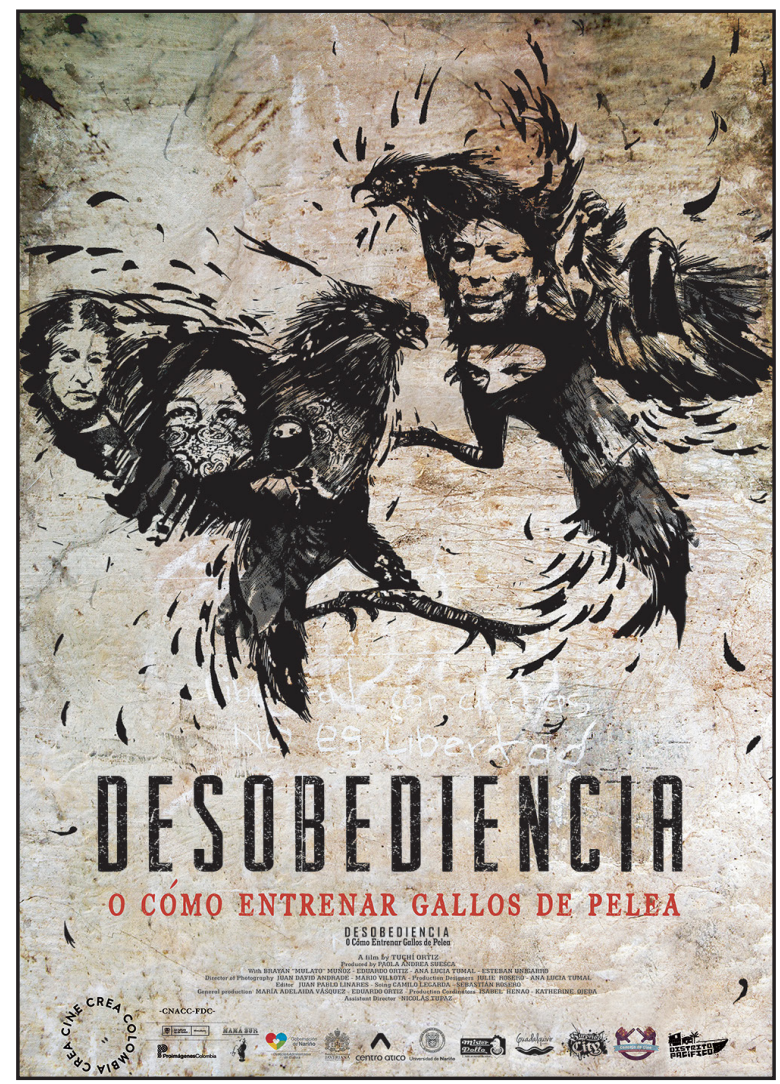

Cubierta de la película Desobediencia o cómo entrenar gallos de pelea Fuente: diseño cartel cinematográfico Ana Lucía Tumal (2018).

* Cómo citar: Ortiz Tobón, S. E. (2019). Reseña de la película Desobediencia o cómo entrenar gallos de pelea de Juan Pablo Ortiz "Tuchi" (2018). Ciencias Sociales y Educación, 8(16), 253-256. DOI: https://doi.org/10.22395/ csye.v8n16a18

Recibido: 19 de julio de 2019.

Aprobado: 12 de noviembre de 2019. 


\section{La resistencia ante las realidades inventadas}

"Nací demasiado alto..." (Ortiz, 2017), se convierte en una frase de despedida pero de renacimiento, es el adiós que deja el inconforme, el que está dispuesto al cambio.

Este texto surge de dos fuentes principales: la primera y primordial es la de haber hecho parte del proyecto en la lectura del guion, y haber vivido esta idea interpretando al "Comandante Segundo" en la película Desobediencia o cómo entrenar gallos de pelea (Ortiz, 2017); la segunda está inscrita dentro de una investigación desarrollada en la Maestría en Sociología de la Universidad Nacional; la cual a través del análisis de diferentes formas de resistencia ante la compleja realidad en la que habita la sociedad, encontró que una de las formas de resistir encuentra la desobediencia como mecanismo de respuesta ante lo que se cree injusto, y se impone de manera agresiva por encima de los ideales y conceptos que se gestan en el individuo y la comunidad (Ortiz, 2019).

La humanidad está compuesta de seres desobedientes, seres que nacen para abrir puertas, pero la sociedad tiene la tarea de encasillarles dentro de lo debidamente aceptable y lo correctamente expresable. Generación tras generación, la civilización se ha obligado a crear normas, leyes, mandamientos, fábulas y razones suficientes para poder meter a niños soñadores dentro de la realidad de un pupitre, a curiosos investigadores dentro de los parámetros del método, a artistas innatos dentro de escuelas de arte que reproducen realidades entendibles y subastables.

En el año de 1966, Krishnamurti (1993) planteaba que la única revolución real consistía en revolucionarse, lo que lleva al individuo a encontrar dentro de sí mismo al mayor contradictor y al mayor creador, el que permanece inmóvil y soñando para despertar y reconstruir los caminos o para desandarlos; sin embargo, gran parte de las personas permanecen en un cómodo letargo ajeno a los sueños y las ideas que le ocurren, y paulatinamente se destruye la curiosidad que llevó al humano a las estrellas y queda un ser con miedo, un ser incoherente con aquello que siente y piensa. Seres amaestrados que no esperan una condena a sus pecados: el pecado de asesinar su alma contradictoria, el pecado de negar el alma creadora de mundos, el pecado de ser asesinos de la inocencia que recuerda los sueños y se propone hacerlos realidad.

Los humanos creen ser la cúspide de la evolución, creen ser la creación imperfecta de dioses perfectos, creen ser el instrumento favorito de los soberanos del mundo, así que parafraseando a Krishnamurti (1993), se podría entender que el perdón sincero es perdonarse arriesgándolo todo por encontrar ese poco de plomo que logre proteger y desandar los caminos, que revolucione el espíritu y 
permita pensar que la sociedad que se implantó es, al igual que dios, la sociedad que condena, pues la vida noble y eterna enseña que somos simplemente seres desnudos e ignorantes de las preguntas fundamentales, preguntas que se responden al desobedecer.

Desobediencia, o cómo entrenar gallos de pelea (Ortiz, 2017) no es la caricatura odiosa de una revolución conducida por las hegemonías ideológicas, es una revolución cruda que se construye al interior de cada una de las desobediencias cotidianas de cada ser, la revolución de adaptarse, de ser, de reconocer y cambiar y al ser cambio es perdón profundo, pero no aquel perdón magnánimo y vistoso del circo de la política que acalla públicamente la orden, "que les corten la cabeza" (Carroll, 2012) sin abrir la posibilidad de escuchar, de entender el origen y permitir escoger el destino rebelde.

La analogía del perdón profundo con el plomo en Desobediencia, o cómo entrenar gallos de pelea (Ortiz, 2017), se puede entender como el blindaje que se busca para hacer invulnerable al ser, el pozo profundo que se cava y que no ofrece nada más que desazón en la búsqueda, pues el perdón sincero nada tiene que ver con el desagravio por los dolores causados, es más cercano a la compensación por la cadena interminable de causa y efecto de cada paso por la vida, porque la sola presencia en el mundo ya es condicional para mantener un comportamiento coherente con la vida ajena, con la propia, con el socavón donde se encuentra de frente el perdón.

Cuestionar debería ser ley (Thoreau, 2013), debería persistir en cada quien la posibilidad de ser crítico ante lo que le rodea, ante los otros que acompañan y los otros que deciden; crítico ante el cemento o el parque encerrado dentro de cuatro calles impersonales; cuestionar lo normalizado, el equilibrio impuesto que asume la sociedad como progreso, como desarrollo que ha encerrado a la gente dentro de confortables y hermosas cárceles que les protegen del afuera. Cuestionar el comportamiento propio, cuestionar el haber perdido la inocente rebeldía, la pueril y fantástica creatividad, la posibilidad de morir y renacer, completo y nuevo cada día (Agualongo, 2018).

Desobedecer en el vacío es agotar la energía, es gritar dentro de ataúdes esperando a ser escuchado. Desobedecer se convierte en un conocimiento profundo del sistema, de la norma, de la sociedad, para desobedecer hay que encontrar las fracturas de la estructura, las aristas que hieren a los rebeldes y condicionan a los débiles. Desobedecer es abrazar el miedo con la conciencia plena de la temporalidad, haber encontrado las armas necesarias para combatir la mediocridad propia y vulnerar la ajena. Desobedecer es de sabios y de soñadores, de trabajadores de la vida, de aquellos que no se limitan por los sentidos y que abren caminos, pues los pasos marcados en la tierra no les bastan (Agualongo, 2018). 


\section{Referentes}

Agualongo, A. (2018). Caleidoscopio Sur. Recuperado de https://caleidoscopiosur.blogspot.com/2018/:

Carroll, L. (2012). Alicia en el país de las maravillas. Madrid: Nórdica.

Krishnamurti, J. (1993). La revolución fundamental. Buenos Aires: Kier.

Ortiz, J. (director). (2017). Desobediencia, o cómo entrenar gallos de pelea [cinta cinematográfica]. Colombia. Producciones Mamá Sur.

Ortiz, S. E. (2019). La normalización de la violencia, una de las causantes del miedo en los colombianos. UN. Periódico digital. Recuperado de https://unperiodico.unal.edu.co/pages/detail/la-normalizacion-de-la-violencia-una-de-las-causantes-del-miedo-en-los-colombianos/

Thoreau, H. (2013). Sobre la desobediencia civil. Medellín: Universidad de Antioquia.

Tuchi, J. P. (2018). Desobediencia, o cómo entrenar gallos de pelea [Película]. Estudio: producciones Mama Sur. 